\title{
Migration and Recruitment of African Nurses in the UK: Between the Primacy of National Imperatives and Global Openness
}

\author{
Angèle Flora Mendy*
}

\begin{abstract}
In a globalized health market, what are the public policies that allow the United Kingdom (UK) to employ African migrant nurses to meet the health needs and to satisfy national and international public opinion? This is the question the article below asks. It is based on an analysis of the UK migration regulation policies and interviews with African migrant nurses in the UK. It uses a neo-institutionalist approach to explain the capacity of public policies to adapt and change in response to imperatives by the use of "room for manoeuvre". Keywords: African Nurses, migration, public policy, United Kingdom, globalization

\section{Migration et recrutement d'infirmiers/ières africains au Royaume-Uni : entre la primauté des impératifs nationaux et l'ouverture au marché international}

Résumé: Quelles sont les politiques publiques qui permettent au Royaume-Uni d'employer des infirmiers/ères africains pour répondre aux besoins de santé et satisfaire l'opinion publique nationale et internationale? C'est la question que pose cet article. Il se base sur une analyse des politiques de régulation des migrations et sur des entretiens avec des infirmiers/ières africains. Il utilise une approche néo-institutionnaliste pour expliquer comment les marges de manœuvre des politiques publiques sont utilisées pour privilégier les impératifs nationaux. Mots-clés: Infirmiers/ières africains, migration, politiques publiques, Royaume-Uni, globalisation

\section{Migration und Rekrutierung afrikanischer Krankenschwestern nach Grossbritannien: zwischen dem Vorrang nationaler Imperative und der Offenheit für den internatio- nalen Markt}

Zusammenfassung: Welche öffentliche Politik ermöglicht es dem Vereinigten Königreich, afrikanische Krankenschwestern und -pfleger zu beschäftigen, um die Gesundheitsbedürfnisse zu befriedigen und die nationale und internationale öffentliche Meinung zu befriedigen? Das ist die Frage, die dieser Artikel stellt. Er basiert auf einer Analyse der Politik zur Regulierung der Migration und auf Interviews mit afrikanischen Krankenschwestern. Er verwendet einen neo-institutionalistischen Ansatz, um zu erklären, wie der Handlungsspielraum der öffentlichen Politik genutzt wird, um nationalen Imperativen Vorrang einzuräumen.

Schlüsselwörter: Afrikanische Krankenschwestern, Migration, Öffentliche Ordnung, Vereinigtes Königreich, Globalisierung

Faculty of Social and Political Sciences, University of Lausanne, CH-1015 Lausanne, angele.mendy@ unil.ch 
For nearly four decades, the migration of health professionals, specifically from the South to the North, has continued to make international headlines. The global shortage of health workers and its consequences on health systems are among the reasons. This phenomenon is not new, but the advent of globalization and the General Agreement on Trade in Services (GATS) ${ }^{1}$ gave it special significance. Issues regarding the international recruitment of health workers was added to the international agenda in 2004 by the World Health Organization (WHO), due to concerns regarding the unfavorable impacts on countries of origin (WHO 2004). Their negative effects were highly publicized in the United Kingdom (UK) and led to the introduction and adoption of the restrictive recruitment measures known as The UK Code of Practice for the international recruitment of healthcare professionals (DH 2004). The UK Code of Practice is a 19-page text that responds to international concerns about the active recruitment of healthcare professionals from developing countries. According to its preamble, the UK Government "recognizes the historical importance of international recruitment of health care professionals to the effective functioning of the NHS" DH 2004, 3. However, concerns related to the impact recruitment may have upon the healthcare systems of developing countries also needed to be addressed. In recognition of this the World Health Assembly called for countries to mitigate against the adverse effects of migration of health personnel. The UK Code of Practice is the key element of the approach undertaken by the UK to address this issue (DH 2004, 3).

Countries, "notably Cuba, China, India and the Philippines", counted on the export of their health professionals as part of their in-country development policies (WTO/WHO 2002, 18) while others, which suffered from insufficient health professionals, denounced this practice. However, considering the combination of GATS requirements and the imperatives of countries' domestic markets two realities were made clear. On the one hand, obtaining the positive effects of such trade required political and economic preconditions and conditions that were difficult to fulfil for most countries of origin (Woodward et al. 2002). In their four points of analysis, Woodward et al highlight the conditions and prerequisites for globalization needed to obtain a positive influence on the health of low-income populations. As an example, here is the first:

1 The health applications of GATS services involve four modes. Mode 1: Cross-border supply, e. g. provision of diagnosis or treatment planning services in country A by suppliers in country B, via telecommunications ('telemedicine'). Mode 2: Consumption abroad, e. g. movement of patients from country A to country B for treatment. Mode 3: Commercial presence, e. g. establishment of or investment in hospitals in country A whose owners are from country B. Mode 4: Presence of natural persons, e.g. service provision in country A by health professionals who are nationals of country B (WTO/WHO 2002, 48). It is modality 4 that sets the legal frameworks for migration and international mobility. 
... it is essential that the positive economic benefits of globalization benefit all countries, especially low-income countries. This means ensuring that changes in international rules and international institutional arrangements fully reflect the needs of developing countries. It also means removing major impediments to the development of the international economy, including the persistent debt problems of low-income countries, the chronic weakness and instability of commodity markets, restrictions on access to developed country markets and the volatility of international financial flows that generate financial crises. (Woodward et al. 2002, 38)

Despite this, national labor markets are actually rigorously protected by most of the destination countries, and therefore this simplifying discourse is out of step with the realities of a globalized market. According to neoliberal logic, the globalized market is theoretically borderless and open to all health workers (Dollar 2001). This is beneficial to both countries of origin and countries of destination, as well as to the migrant health workers themselves - a "win-win" situation for all.

Migrant health professionals, especially from non-European Union (EU)/ European Economic Areas (EEA), are restricted with respect to where they can migrate to (Mendy 2016), as countries have carefully created barriers to entry and segmented their labor markets. Non-EU/EEA migrant health professionals, mainly from the South, also face uncertainty regarding their working conditions, which oscillate between salaries and conditions comparable to their Western counterparts or sub-legal conditions, low pay and recognition for performing at the same skill level (Mendy 2019). The health labor markets of receiving countries are fundamentally linked to health systems which have specific recruitment logics, for example acceptance/integration or rejection/marginalization. Official and unofficial strategies are developed in the form of public policies which subtly enable countries to deal with shortages of health professionals and are responsive to pressures of health needs, but also satisfy international commitments related to migration and mobility.

However, little is known about the functioning of these national public policies and how, over time, they have been deployed as mechanisms of migration control. Therefore, this paper will use the case of the UK and African migrant nurses to explore the question in greater depth. In terms of international recruitment of non-EU/ EEA health professionals, the UK is an example of a country which broke with the liberal tradition of opening its health labor market by gradually introducing restrictive policies towards overseas health professionals at the end of the 1990s (Mendy 2018). However, whatever their restrictive character, the UK's public policies did not entirely close the internal market to non-EU/EEA international recruitment but gave the UK enough room for manoeuvre to manage and control its own labor market, therefore ensuring the UK could give priority to its own domestic objectives and agendas. 
The aim of this paper is to question the fundamental nature of these migration regulation policies by applying the room for manoeuvre analysis. It will first explore how the policies work to regulate the entry of non-EU/EEA migrant health workers and, secondly how these polices give priority to national imperatives. The paper will first detail the theoretical and methodological framework deployed before moving onto an analysis of how public policies have allowed British authorities to retain control over their domestic market in the globalized health context. This paper will then move to analyze the new institutional context and the implementation of migration regulation policies with specific focus on those relating to non-EU/EEA health migrant workers. Finally, it gives voice to African migrant nurses and their perspective with regards to these policy changes.

\section{Institutions, Public Policies and Actors}

Domestic work migration policies, and more specifically health migrant workers policies, have received little academic attention despite their impact and use as a mechanism for domestic migration and market control. The study of international migration of non-EU/EEA health professionals, as well as their recruitment in destination countries, tends to show how mechanisms of domestic migration and market control play a key role in regulating the internal labor market. The UK is a perfect illustration of a market model that is open to international recruitment but has become progressively protective in terms of regulating the internal health market. The UK logic of political adaptation when national interests are at stake does not only concern the recruitment of foreign health professionals but, in fact, is the basis of British immigration policy (Coleman 1995). Theoretically, two perspectives, the Historical Neo-institutionalism (cf. North 1990; Merrien 1993; Pierson 1996) and the Public Policy Analysis (cf. Cairney 2012) can be used to explain the fundamental logics of public policies that act as control mechanisms. First, they enable relevant interpretations of the rules of institutions (or governments, or States) that implement public policies and second, they explain the fundamental characteristics of such public policies and their capabilities to give room for manoeuvre to government or state actors who manage the migration of health workers. They also stress "the importance of actors", in this case health authorities, as well as "the rules of the game" (cf. Howlett et al. 2009, 139-142), which give priority to national imperatives that come into play within the regulation process.

\subsection{Meanings and Rules of Institutions and Public Policies}

The neo-institutionalist perspective emphasizes the importance of institutions in defining public policies. Institutions are defined as the rules of the game, formal and informal, which structure actors' activities through formal collective (legal system) or 
informal (customary) constraints, norms, values and collective rules (North, 1990). Whereas public policies are the rules of the game which facilitate the transaction between actors (Fouilleux 2000, 277). Bauer et al. define public policies as

a course of action (or non-action) taken by government or legislature with regard to a particular issue (...). It emphasizes two constitutive elements. First, public policy refers to actions of publics actors - typically governments - (...). Second, government actions are focused on a specific issue, implying that the scope of activities is restricted to addressing a certain aspect or problem... $(2012,4)$

However, public policies put in place by states to manage their labor markets are "country-specific" (Pierson 1996, 155). This specificity reflects "the nature of the welfare state system with which the state is identified, as well as the characteristics of its health system" (Merrien et al. 2005, 175-179). As a result, the issue of recruitment of foreign health professionals is posed in very different terms in different countries of destination (Mendy 2016). Some countries, such as the UK, operate a liberal model of recruitment, which is reflected in "its employment of large numbers of migrant health workers and active international recruitment policies", which remained the case until the 2000s (Mendy 2018, 322). Countries, such as France operate a corporatist model, and hire few foreign health workers, whilst also placing a hold on their domestic recruitment (Mendy 2019). These specific control mechanisms are historically implemented by institutions to regulate and structure the interactions of actors, influence expectations, define what is legitimate and what is not within a country. If characterized by long-term arrangements, they can undergo changes under certain conditions without compromising their room for manoeuvre (Pierson 1996). But when does the policy change occur?

\subsection{Change and Actors of Public Policy}

To provide an explanation of the changes in British recruitment policies in the 1990s for non-EU/EEA health professionals which involved not only a move towards more restrictive policies but also to a change in the actors involved, the historical neo-institutionalism frame will be used. The historical neo-institutionalism theoretical frame prioritizes critical historical moments that create unexpected consequences in certain public policies. These unexpected effects have pushed officials to call into question the paradigm which has inspired current policies (Merrien 1990; Pierson 1996; Hall et al. 1997). Paradigm shifts occur at a moment of "crisis", conceptualized by Kingdon and Stano (1984) as "windows of opportunity" that allow for the possibility of reinvigorated and inspirational policies. The moments of crisis - the period of international recruitment controversies - 
denote periods of disorder in the seemingly normal development of human affairs, along with widespread questioning or discrediting of established policies, practices, and institutions. (Nohrstedt and Weible 2010,3)

In these contexts of openness, new ideas (Jobert and Muller 1987) are developed by "advocacy coalitions" (Sabatier 1988, 139). For example, the British Medical Council, in publications in the Lancet, called for priority to be given to the establishment of ethical rules which would guide the management of national health human resources and international recruitment. On an international level, controversies were raised not only by advocates from the countries of the South, but also by certain governments, researchers and experts from the United Nations (UN) (Mendy 2016). By pronouncing the recruitment of health workers from low income countries as indecent and unethical ${ }^{2}$, advocacy coalitions ignited debate on an international level. According to Roe (1994), the role of advocacy coalitions, supported by international public opinion, is fundamental to legitimizing new conceptions of social reality from which total, or partial, new policies can be introduced. The exercise of persuasion consists of sharing their political "framing" with an ever-wider group of actors. In this case, the argument was for the necessity of recruitment policies to consider the right of low-income countries to adequate health professionals and ensuring this was defended on an international level. By exposing a new way of constructing international recruitment, advocacy coalitions attempted to delegitimize old policies, in this case intensive recruitment policies, by proposing new procedures (Roe 1994). However, as Sabatier (1988) shows, pressure from advocacy coalitions is not enough to introduce reforms. To do this, the political context and the institutions must also allow for it. This was certainly the case in the UK in the late 1990s and early 2000s, when national public opinion, supported by a series of Lancet publications, strongly denounced the policy of intensive recruitment from low income countries. Reforms are easier when a crisis is dramatized, as it makes it possible to accept important challenges (Sabatier 1988) which, without dramatization, can be more difficult to implement, as institutionalized arrangements are likely to have produced lock-in effects (Pierson 1996). In the case of the UK, the reforms introduced were the adoption of a Code of Practice and migration regulation policy reform, but the logic of openness and closure that fundamentally underpins the UK internal market remained intact. This was due to the room for manoeuvre that was built into the regulation of migration policies, which will now be discussed.

$2 \quad$ Numerous articles published in the Lancet including "Medical migration: who are the real losers?" (Bundred and Levitt 2000) rigorously denounced British government policy. This policy favors international recruitment to the detriment of a national solution based on the training of a local health workforce. Its recruitment logic is considered unethical as it deprives the populations and health systems of low-income countries of their health workers. 


\subsection{Migration Regulation Policies and its Room for Manoeuvre}

Theoretically, state authorities have an intrinsic capacity to formulate migration regulation policies that give priority to national imperatives over any other considerations. Migration regulation policies are internal market control mechanisms that provide leeway to prioritize national interests and are by definition flexible and not fixed (Mendy 2019). They are characterized by a more or less broad formulation, sometimes "deliberately ambiguous" (cf. Kübler et Maillard 2009, 64), which provides them with the capability to adapt quickly to new circumstances. Public policies can only be implemented with state authority, and consequently, the room for manoeuvre implemented and defined within the policy from the outset serves the interests of that state. These interests can be multiple; however, two categories are fundamental to the game of political balance: international commitment and national imperatives. In the case of non-EU/EEA health professionals on an international level, this translates to a "Code of Ethical Practice" and on the national level to a shortage of health professionals; this, as well as economic reasons, will, all other things being equal, be prioritized.

Beyond theoretical definitions, how can we reflect analytically on public policy change and the room for manoeuvre it allows? To answer this question, Sabatier $(1988,131)$, in a more heuristic approach, shows that the essential condition for an analysis of change in public policy is to consider a situation with a sufficiently long duration in order to validate the change. Therefore, this paper favors an historical approach by taking into account the evolution of the British public policies related to migration of non-EU/EEA nurses and the perceptions of African nurses who experience the policy changes. Before addressing how the UK migration regulation policies, through room for manoeuvre, meets its political commitments without compromising its national imperatives, the article first presents the methodological framework that underlies it.

\section{Methodology}

This article is based on the results of postdoctoral research conducted on the careers of African migrant nurses in the UK. It is based on an analysis of the UK migration regulation policies and interviews conducted between 2014 and $2019^{3}$ with African migrant nurses. This paper provides public policy analysis, and the 15 interviews selected for this paper complement the analysis of migration regulation policies. Only themes dealing with the impacts of public policies on nurses' careers will be explored in this article. The analytical process favors a historical approach by taking into account the evolution of the British public policies related to migration

3 All the interviews will be the subject of a separate publication on the trajectories of African migrant nurses in the UK. 
of non-EU/EEA nurses and the perceptions of African nurses who experienced the changes. As suggested by the theoretical framework in terms of duration (Sabatier $1988,131)$ the methodological frame considers three periods of recruitment. First, before the implementation of the Code of Practice (1990s), which was a period of intense recruitment of overseas nurses and saw the British health migrant workers recruitment policy criticized because of its "aggressive nature". Second, during the shift of general migration policies and the formulation of the Code of Practice for the recruitment of health workers, termed the transition period (2000s). Third, the context of the implementation of the overseas nurse's new recruitment policy and procedures (2000s and 2010s). Interviews were conducted with African migrant nurses from different nationalities working in the UK, mostly from Nigeria, Ghana, Uganda, Zimbabwe, Gambia, South Africa and Kenya. Interviewees were aged between 26 to 57 years old, and the majority of the nurses interviewed worked within the NHS structure. All interviewees are anonymous and have been given pseudonyms. Interviewees were contacted through the nurses' professional networks and complemented by the use of the snowball sampling technique to recruit further interviewees. Interviews were conducted outside of their workplace and interviewees were given the opportunity to send in additional documentation or answer questions via email. The key criteria for nurses interviewed was that they had had a long-term presence in the UK. This was to ensure the sample included interviewees who were recruited within the controversial period of intensive overseas recruitment. 15 interviews - 13 women and two men - were selected for analysis, this analysis will be discussed in in section 5.3. The themes addressed in the interviews were the following: training and work experiences before, and after, arriving in the UK; the recruitment procedures; their current status; the migration policies related to health recruitment and the impacts of migration policies on their careers. The last theme is the one which has been explored in this paper. Ethical approval for this research was granted by Research Ethics Commission of the Faculty of Social and Political Sciences, University of Lausanne, Switzerland.

\section{The Migration of Non-EU/EEA Nurses in the UK: Between Opened and Closed Labor Market Policies}

For the past few decades the UK has faced a growing need for health personnel and has looked for strategies to attract health professionals, particularly nurses, from Commonwealth countries (Mackintosh et al. 2006). Beyond its postcolonial legacy, there are some specific factors which make the UK of interest to overseas health professionals (Buchan and Sochalski 2004). Due to the nationalization of the health system in 1947, the UK's health system has been characterized as favorable to foreign health workers, which was reflected in UK migration policy (Immergut 
1992; Boswell 2003). During the 1950s and 1960s, the NHS relied on overseas nurses coming from the Caribbean to meet its staffing requirements (Hardill and MacDonald 2000, 684). In the 1960s a severe shortage of nurses led the Health Ministry to approach the Government of Barbados to recruit nurses. After World War II, in addition to West Indian nurses, Irish women formed a second group who were encouraged to migrate, to train and/or work in the NHS (Mackintosh et al. 2006, 105).

In the 1990s, the globalization of health and the GATS gave particular impetus to the international recruitment of health professionals in the UK. International recruitment was officially chosen amongst national political measures to face the shortage in the health sector and to meet the expansion of the NHS (Connell et al. 2007). Nurses were actively solicited from Africa, India and the Philippines, and three main explanations were identified as to why nurses from developing countries would have migrated to the UK: "those coming for educational purposes, individual nurses taking the lead to apply for jobs in the UK, and those actively recruited by non-NHS employers" (Buchan and Seccombe 2004, 24). Objectively, this policy of extensive recruitment of overseas health professionals was justified under the market reference and the theory of comparative advantages (World Bank 1995). The creation of a global market for goods and services under the GATS in its modality 4 - international mobility of health workers - "legitimates the employment of foreign labor" (Mendy 2010, 182). The British immigration policy is described as a policy of opening and closing of the valve. This translates to the UK actively recruiting internationals at a time of need and then halting recruitment when national objectives are met (Coleman 1995). The policy was justified, as it allowed for a recruitment process that reflected the change of political parties and the defense of national interests. As Buchan stressed,

with the coming into power of the Labour Party, the UK therefore stands out as a country where active international recruitment of nurses, and other health professionals, was an explicit national-level government policy response to the need to increase staffing levels in a public sector, government-funded health care system. (2007:1323)

However, in the late 1990s and early 2000s, the British government faced calls to revise its policy of active recruitment due to the negative consequences on developing countries (cf. Bundred and Levitt 2000). Nationally ethical questions were raised about this form of recruitment, which was led by the Lancet's campaign that called for an end to the recruitment of health professionals from developing countries. The campaign, which took place both within the UK and Commonwealth member countries, emphasized the unethical character of recruiting health workers from low-income countries. Before long the campaign garnered international attention and was followed on both national and international levels (Mackintosh et al 2006). 
The result of the campaign saw changes introduced into the UK's overseas recruitment policies of health professionals. The UK adopted a Code of Ethical Practice in 2001 (DH 2001), revised in 2004 (DH 2004), which introduced several restrictive policy measures. Examples included the removal of the health sector from the list of the priority sectors, the "Modernization of Medical Careers" in 2006 (Buchan and Aiken 2008, 27) and the implementation of new registration procedures for overseas nurses in 2014. These reforms marked an important turning point in the migration policy of the health workforce (Mendy 2010). Reforms aimed at minimizing arrivals in the UK of non-EU/EEA health professionals, despite the protests of their professional associations (RCN 2014). The historically liberal and open British model of international health professional recruitment had been supplanted by an increasingly restrictive one (Brau 2011). This shift in policy caused two long term and far reaching consequences. Firstly, it meant that the UK now focused on recruiting healthcare workers from within Europe (Buchan and Aiken 2008). Secondly, the implementation of the Code of Practice bans the UK from hiring health professionals from certain "blacklisted" countries. Most of the African countries among the UK source countries of recruitment are on this list (OCDE 2004, 159-160). As a consequence to these policy changes, the UK was left with the problem of how to address the nation's resistance to the recruitment of health professionals from low income countries, whilst also meeting the domestic need within the NHS for health professionals. However, by analyzing the health migration regulation it can be seen how the UK met this challenge, and the case of the UK perfectly illustrates the interplay of balances allowed through the use of room for manoeuvre.

\section{The New Institutional Context and the Migration Regulation Policies}

\subsection{Shift toward Restrictive Policies and the Key Rules of Room of Manoeuvre}

Recommendations from the Code of Practice (DH 2004) became the foundation of the new guidelines, which outlined the current direction of British policy orientations relating to the migration of health professionals from countries on the "banned" list. In summary, the objective of the Code of Practice was to promote high standards of practice in the recruitment and employment of health professionals at an international level. It was based on the principles that international recruitment of health professionals had to consider the health needs of the countries from which the health professionals originated from and, in addition, recruitment had to be based on a government-to-government agreement.

Furthermore, the Code of Practice recognized international health worker mobility as a long-established practice that should continue and viewed this mobility as a legitimate activity if conducted in an ethical and managed manner. Finally, it recognized that health professionals have the right to move and establish and 
develop their career paths independent of state objectives. In this regard, the Code of Practice reassured health professionals that their employment with the NHS and other health organizations, which comply with the Code of Practice, would provide them with high standards of training and support in their new careers $(\mathrm{DH}$ $2004,4)$. To promote self-sufficiency in the health workforce, the British government rapidly increased its capacity of medical and nursing education on a national level. It also implemented a wage policy to attract and retain British citizens, even if some scholars challenge the basic ideology of this policy. However, according to Mackintosh et al. (2006), the very idea of self-sufficiency at national and EU level is unachievable. One of the main strands of their arguments contends that British health professionals continue to move in a globalized international context. Meaning that while the UK exploited its market advantage in recruiting Englishspeaking nurses from Asia and Africa, it was also the target of OECD country's recruitment policies attempting to solve their own nursing shortages (Mackintosh et al. 2006, 26). As Buchan and Seccombe showed, "the UK is a major player in the international nursing labor market and has to compete with other developed countries" (2004, 20-21). The authors however stress two critical findings. Firstly, they show that an "increased activity by the USA and other recruiting countries into English-speaking international labour markets could make it more difficult for the UK to recruit". Secondly, the "strict compliance with Code of Practice will mean that some recent main source countries are no longer acceptable targets" (Buchan and Seccombe 2004, 20-21). Currently, 50 of 57 African countries are blacklisted, including South Africa (DH 2004) which was one of the four most important source countries - along with the Philippines, India and Australia - providing international nurses to the UK in 2003. In fact, international recruitment is recognized as having made a critical contribution to staffing growth, particularly in England (DH 2004; Home Office 2006), and it remains one of the four policies - improve retention, new intakes, returners, and international recruitment - implemented to achieve an increase in NHS nurse staffing.

Given the historical legacy of the UK's recruitment and employment policies of health professionals, the implementation of restrictive measures was called "radical" (cf. Brau 2011,3). The policy measures were particularly prohibitive (Buchan and Aiken 2008) whereas, traditionally, for health professionals coming from the Commonwealth, occupational mobility was "an aspect commonly accepted, valued and desired" (Mackintosh et al. 2006, 5). The restrictive measures were also denounced as potentially discriminatory and ineffective. Instead of protecting migrant health professionals, they were seen as having the potential to increase the vulnerability of health care professionals as equal treatment was not guaranteed (Allan et al 2004; Alexis and Vydelingum 2007). Additionally, the measures had the potential to create a category of health professionals discriminated against because of the economic situation in their countries of origin. Therefore, measures that were intended to be 
ethical instead appeared as discriminatory to non-EU/EEA migrant health professionals, despite the apparent guarantees from the authorities (NHS England 2013).

Meanwhile, the UK health care system faced a great dilemma between ethical recruitment and national imperatives, namely health personnel shortage. It is precisely on this point that the public policy decisions taken can be interpreted as a game of political equilibrium. This implies the use of the room for manoeuvre inherent in UK regulation migration policies.

\subsection{Connections between Immigration and Health Workers Policies and Impacts on African Nurses}

Taken together, the connections between immigration and non-EU/EEA health workers policies follow the same logic of change and closure. Policies that were once open were now restrictive, especially in relation to the domestic priorities of the economy and health sectors. African migrant nurses and by extension the African migrant health professionals are particularly affected and extremely concerned by the change in immigration policies (Brau 2011, 31-33).

\section{The Points-Based System Policy and the Code of Practice}

While discussions related to the international migration of overseas health personnel were taking place at national and international levels, the Labour Government that took office in 1997 launched a broader consultation on the reforms of immigration policies. Considered "the most significant change to managed migration in the last 40 years" (Home Office 2006, 5) the consultation over the Points-Based System (PBS) policies closed in November 2005 and led to several key reforms within the health sector. The reforms included the official publication of the UK Code of Practice (Code of Practice) for overseas health personnel in 2004, and the reform of medical studies that modernized medical careers and gave priority to national physicians in training as well as those from other EU countries. The PBS was the Government's new approach "to managing the flow of migrants coming to the UK to work or study". In the foreword of the PBS it stated:

The UK needs a world class migration system to attract the brightest and the best from across the world, while at the same time being more robust against abuse. We welcome people who come to this country to work and to study, but we need to ensure that they come here legitimately (...). New points-based system will allow us both to manage migration and secure our borders against those who want to abuse them. (Foreword of Charles Clarke, Home Office, 2006)

As Brau underlined,

the introduction of the PBS is an attempt to assert control over and manage immigration as demanded by British public fears over the economic 
and social effects of non-European immigration. Emphasis is placed on the economic benefits of migration, signaling a move away from previous policies that focused mainly on addressing public concerns over socio-cultural implications of migration. $(2011,2)$

The concept of "managed migration" that was predominantly launched during this period meant, not only controlled migration, but also looked at selecting workers based on the interests of the UK economy (Murray 2011, 10).

As regulation policies, the PBS and the Code of Practice have several similarities. They are both explained "by general public concerns over economic and social consequences of migration" (Brau 2011, 4) and both have been characterized, to some extent, by their controversial aspects that were considered discriminatory. The $\mathrm{PBS}$ is perceived as

the latest development in the contested and polemical area of post-World War II British immigration policy, introduced in the context of problematic integration issues and the immigration policies. (Brau 2011,3)

The Code of Practice appeared as the result of a controversial debate on ethical issues relating to international recruitment. Both the PBS and the Code of Practice were the responses of politicians and policymakers to public demands with regards to formulating immigration policy (Brau 2011, 5). The PBS policies exclusively concern non-EU/EEA migrants, and the original document states:

The Points-Based System will be designed to set the criteria under which nationals of Non EU/EEA countries will apply to come or to remain in the $U K$ to work, train or study. (Home Office 2006, 1)

African nurses who basically come to the UK mainly for three purposes: "work, train or study" were extremely concerned about these policy developments. With the PBS, African nurses must first obtain a work permit to allow them to enter the UK in order to undertake the registration procedures while almost all African countries are on the banned list (cf. OCDE 2004, 159-160). According to the RNC the policy restrictions impact negatively on overseas nurses because, before the reforms, the Post Study Work (PSW) position allowed graduates to work in the UK for a two-year period following their study. This has now been abolished. In addition, the increase in fees relating to immigration and nationality applications discourages most of the overseas nurses from coming to the UK or staying (RCN 2014).

\section{The New Registration Procedures for Non-EU/EEA Nurses}

Beyond the immigration policy change, the registration procedures which give authorization to practice nursing in the UK also faced changes, which came into effect in October 2014 and were recommendations from the Code of Practice, as well. According to the Nursing and Midwifery Council (NMC), the aim was to simplify the procedures 
in the interest of the overseas health professional (Nursing and Midwifery Council 2011). The following description of the new registration procedures provides a better understanding of how African migrant nurses perceive the policy changes. The practice of nursing in the UK requires several obligations that all nurses must comply with. Among these obligations the procedure of registration is the first step. Nurses who desire to practice in the UK must be officially registered with the NMC. Some points of the procedure are common to all nurses, regardless of the county of origin where they undertook their training. However, some are differentiated according to three categories: nurses trained in the UK, nurses trained in the EU and EEA countries, and non-EU/EEA nurses. All qualified nurses have the opportunity to register for one or more specialties after completion of the registration procedure (Nursing and Midwifery Council 2011). Consequently, they can work in the National Health Service (NHS) and the private health care sector, including private hospitals, nursing homes or in the community. Similarly, all nurses registered with the NMC are required to practice in accordance with the rules and standards set by the NMC (Royal College of Nursing 2013). Nurses are required to renew their registration periodically and the frequency of renewal depends on the country of origin where their training was completed: for instance, three years for those who have been trained in the UK and EU member states, and annually for non-EU nurses (Nursing and Midwifery Council 2011). During every renewal two standards set by the NMC must be met: (1) the continuing professional development (CDP) standard and (2) the practice standard. Meeting these standards mean that nurses can demonstrate that they have undertaken 35 hours of extra study relevant to their practice and completed 450 hours of practice during the first three years prior to the renewal of registration. Whatever the terms of employment are, every nurse must provide evidence of meeting these standards in order to maintain their registration as a nurse with the NMC.

Compared to the new registration procedure, the former application process for non-EU applicants was composed of two steps: the pre-registration stage and the registration procedures. The registration procedures have undergone changes, particularly with the introduction of the International English Language Testing System (IELTS) and the biggest change has been the introduction of the Overseas Nursing Programme (ONP). As mentioned in the NMC publication "the new process will replace the Overseas Nursing Programme (ONP) (...) with a more robust application process with a test of competence at its heart" (NMC 2014, 1). In fact, the test of competence and the practical exam (OSCE) are the two main reforms in the overseas application process. Like the ONP, the test of competence is based on UK education and competence standards for pre-registration. It consists of two parts: a computer multiple choice exam, which is accessible in many countries around the world as well as a test of competency and a practical exam (OSCE), held in the UK. According to the NMC, this allows candidates to plan their financial and 
domestic arrangements for travelling to the UK. Applicants are not required to have a sponsor or employer to complete the process and so will be less at risk concerning the exploitation and poor recruitment practices that have been reported in the past (NMC 2014, 4). The new application process is now longer and more restricted and takes, on average, a year to complete (NMC 2011). However, when African migrant nurses are asked about their perception of new migration policies, the answers vary from person to person with important converging arguments. They may recognize the simplification of procedures as outlined in the NMC, but all agree that the new procedures are lengthy and have a high financial cost for those involved.

\subsection{African Migrant Nurses Perceptions of Policy Change}

The interviews reveal two main areas of concern that African migrant nurses have in relation to the migration policies and registration procedures. These will now be explored below.

First, the experiences with procedures. All the interviewees agreed that the migration policies were becoming increasingly restrictive and constraining. Those who had experienced the registration procedures and the visa application after the implementation of the PBS policy stressed the higher level of costs and longer length of procedures involved. Irrespective of which countries the non-EU/EEA nurses were from, they frequently referenced the "need to call the NMC service to learn about their case" which is expensive from abroad. The need to save money was also frequently referred to, as before committing to migrating, health professionals had to ensure a level of savings because during the period of attending the ONP - a period called adaptation - they are required to support themselves financially and assume the entire cost of registration. In this sense, they all mentioned that they felt a high level of indebtedness and financial vulnerability before they started employment.

At least you know you need to prepare financially before you come here. But your savings are running out pretty fast. But I spent a lot on phone calls with the NMC. Sometimes you still want to know if everything's okay with your case. You call and it costs you a lot from there (...). I can't speak for the others, but it was really difficult (...). It is still the local currency (his country's currency). (NUK3680817)

In addition, they said they needed to find themselves a place at a UK university to follow the adaptation program. Health care professionals all concluded that the process was "emotionally" and "financially" demanding:

(...) Overseas nurses really have to have a desire to come to the UK or have no choice but to accept all the difficulties related to the immigration and registrations procedures. (NUK3160414) 
Furthermore, there is some misunderstanding about the IELTS for nurses from English-speaking countries who have completed all their schooling and training in English. According to one interviewee:

with the recent tightening of immigration criteria, the English examination takes much more time because of the small number of places where the English test can be taken in the sending country, and factoring in the attendant risks of delay (...). (NUK2690715)

and another stated,

we raise awareness about discrimination, but the legal discrimination we suffer and that is imposed on us by the policies, nobody talks about it and tries to find a solution for us. We are the ones who feel the brunt of the policy changes the most. (NUK4130514)

It seems, however, that migrant nurses from non-English-speaking countries must take this language test to facilitate communication:

I don't have any problem taking this test. I just think that people who really need to take it don't. I have nothing against those people, but they are the ones who need the test to make themselves understood by the patients. That's where things are done wrong honestly. (NUK55240918)

It is interesting to note that those who underwent the immigration and registration procedures in the late 1990s and early 2000s, which corresponded to the period of controversy surrounding the recruitment of professionals from low-income countries, said that they did not feel the restrictions of the policies. Consequently, most of them did not comment on the migration regulation policies, including the procedures. It can be concluded that this was due to the fact that the restrictive measure were yet to be implemented during the discussion period and therefore, African migrant nurses were yet to feel impacts. This shows how there is a time lag between policy formulation and actual implementation. However, another explanation could be, as shown in previous studies (Mendy 2018, 332), that employers tend to be less concerned with international debates than with the compliance of qualifications and skills within the standard of care. This was also been confirmed by some of the interviewees and according to some nurses discussions regarding international debates were not necessarily taking place in the hospital context. One interviewee stated:

Is it ethical or not to recruit health professionals from non-EU/EEA countries, these questions are not part of our daily life in hospitals. Patient care seems to be a priority. Now, this does not mean that it is not important to us. (NUK1160414) 
Second, the way in which political decisions are viewed. They are considered to be discriminatory in their formulation even though, paradoxically, they say, the UK will not be able to move health workers from abroad:

What I can say is that we no longer know what to expect with that Brexit(...). It may affect us, but if we have a stable job, I don't think we have to worry because the NHS needs foreign labour. (NUK60120719)

For the nurses interviewed after 16 July 2016 (the vote went in favour of Brexit) their comments on the impact of the policies on their careers systematically mentioned the uncertainties surrounding the consequences of Brexit.

We were surprised by all this. I think those who have a choice like the EUIEEA nurses are going to leave. (...). They can find work elsewhere. (...). It's more complicated for non-EU/EEA people. But let me tell you that I'm focusing on my work because I have family obligations and irregular hours, I'm not going to add to my stress... (NUK41180817)

Not all African nurses have strong opinions on policy and will focus more on the forms of discrimination sometimes felt in their workplace than what the migration policy might be. These discriminations are illustrated through accounts of their social interactions in the workplace and lived experiences.

I do not read immigration policies to find out whether they are always formulated against us. It's simple, you've done the procedures, you know the difficulties, the challenges, the length of procedures and so on, and then you move on, when you finally start working. But, do you know that there are other discriminations that we can experience that are not written down somewhere (...). You feel it (...), sometimes you defend yourself, sometimes you get over it, sometimes it becomes banal. The law can change, but some things are hard to change. (NUK17270215)

\section{Conclusion}

The analysis of policies regulating the migration of non-EU/EEA health professionals through the example of the recruitment of non-EU/EEA migrant nurses in the UK has shown that the globalization of the health labor market remains to be qualified when it comes to looking at the different logics of national health markets. The case of the UK, known in the 1990s to be the liberal model par excellence for the recruitment of non-EU/EEA health professionals, is a perfect illustration of this. Although the UK remains sensitive to the international community's invective on the consequences of over-recruitment, particularly from sub-Saharan Africa, the 
reforms undertaken are sufficiently well formulated to leave the British health system players enough room for manoeuvre.

The Code of Practice for the international recruitment of healthcare professionals, the PBS and the non-EU/EEA nurses' new registration procedures are seen as migration regulation policies, which enable the UK to meet both its international commitments and its economic and health imperatives. Whilst not necessarily explicit about their objectives of control, selection and regulation of migration, they do give authorities in charge of implementing them a very wide room for interpretation. This room for manoeuvre, built within the policies, has also been found to be beneficial as it allows for policies to give primacy to national imperatives. Although the UK has enacted ethical rules of recruitment to satisfy national and international public opinion through its Code of Practice, the latter does not deprive the UK health system of international health professionals. Active recruitment from most developing countries is prohibited, yet health professionals from these countries who enter the UK independently are not banned from recruitment. Private recruitment agencies have not implemented the ethical recruitment principles and therefore, are not concerned with, or bound by, the list of banned countries for recruitment. Government-to-government agreements for the recruitment of health professionals are not covered by the prohibition. The NHS can also recruit non-EU/EEA nurses within the UK who may have previously entered the UK and who were recruited by private agencies, and who do not adhere to the Code of Practice as well.

Similarly, the PBS also allows for a very broad room of interpretation and therefore explicitly favors the economic interests of the UK. The PBS recognizes the vital role of migration to the UKs economy and aims to select migrants who are profitable to this end. This can be seen clearly in this statement from the Home Office: "Better identifying and attracting of migrants who have most to contribute to the UK" $(2006,1)$.

The PBS, as well as the new registration procedures for non-EU/EEA, are all very important migration mechanisms for the UK. On the one hand, the costs of the procedures are very high for prospective immigrants. On the other hand, they are ultimately an undeniable mechanism of regulating migration flows. The room for manoeuvre that allows the UK to regulate its internal market in favor of national interests is not specific to recruitment policies for migrant health professionals but is fundamentally linked to the logic of the UK internal market. Beyond this observation, putting the theoretical framework into perspective with the elements of the analysis shows that room for manoeuvre is an intrinsic part of public policy creation. 


\section{$7 \quad$ References}

Alexis, Obrey, and Vasso Vydelingum. 2007. Migrating Registered Nurses in the UK: Black and Minority Ethnic Overseas Nurses' Perspectives. International Journal of Health Care Quality Assurance 20(5): 441-452.

Allan, Helen, John Larsen, Karen Bryan, and Pam Smith. 2004. The Social Reproduction of Institutional Racism: Internationally Recruited Nurses' Experiences of the British Health Services. Diversity in Health \& Social Care 1(2): 117-125.

Bauer, Michael, Jordan, Andrew, Green-Pedersen, Christoffer, and Adrienne Héritier. 2012. Dismantling Public Policy. Preferences, Strategies, and Effects. Oxford: University Press.

Boswell, Christina. 2003. European Migration Policies in Flux: Changing Patterns of Inclusion and Exclusion Chatham House Papers. Oxford: Blackwell.

Brau, Elise. 2011. UK Immigration: Motivations Behind the Introduction of the Points-Based System. Migration Studies Unit Working Papers 1. London: London School of Economics and Political Science.

Buchan, James. 2007. International Recruitment of Nurses: Policy and Practice in the United Kingdom. Health Research and Educational Trust 42(3): 1321-1335.

Buchan, James, and Ian Seccombe 2004. Fragile Future? A Review of the UK Nursing Labour Market in 2003. London: Royal College of Nursing.

Buchan, James, and Julie Sochalski. 2004. The Migration of Nurses: Trends and Policies. Bulletin of the World Health Organization 82: 587-594.

Buchan, James, and Linda Aiken. 2008. Solving Nursing Shortages: A Common Priority. Journal of clinical nursing 17(24): 3262-3268.

Bundred, Peter E., and Cheryl Levitt. 2000. Medical Migration: Who Are the Real Losers? The Lancet 356(9225): 245-246.

Cairney, Paul. 2012. Understanding Public Policy. Theories and Issues. Palgrave Macmillan.

Coleman, David. 1995. Immigration Policy in Great Britain. Pp. 113-136 in Migration Policies: A Comparative Perspective, edited by Friedrich Heckmann et Wolfgang Bosswick. Stuttgart: Editions Enke.

Connell, John, Pascal Zurn, Barbara Stilwell, Magda Awases, and Jean Marc Braichet. 2007. Sub-Saharan Africa: Beyond the Health Worker Migration Crisis? Social Science \& Medicine 64(9): 1876-1891.

Department of Health UK (DH). 2001. Code of Practice for NHS employers involved in the international recruitment of healthcare professionals. London: Department of Health.

Department of Health UK (DH). 2004. Code of Practice for the International Recruitment of Healthcare Professionals. London Department of Health.

Dollar, David. 2001. Is Globalization Good for Your Health? Bulletin of the World Health Organization (79)9: 827-833.

Fouilleux, Eve. 2000. Entre production et institutionnalisation des idées. La réforme de la politique agricole commune. Revue française de science politique 50(2): 277-306.

Hall, Peter A., and Rosemary C.R. Taylor.1997. La science politique et les trois néo-institutionnalismes. Revue française de science politique: 469-496.

Hardill, Irene, and MacDonald, Sandra 2000. Skilled International Migration: The Experience of Nurses in the UK. Regional Studies 34(7): 681-692.

Home Office. 2006. A Points-Based System: Making Migration Work for Britain. Cm 6741, TSO, Norwish.

Howlett, Michael, Michael Ramesh, and Anthony Perl. 2009. Studying Public Policy. Policy Cycles \& Policy Subsystems. Third Edition. Oxford: Oxford University Press.

Immergut, Ellen M. 1992. Health Politics. Interests and Institutions in Western Europe. New York: Cambridge University Press. 
Jobert, Bruno, and Pierre Muller. 1987. L'Etat en action. Politiques publiques et corporatismes. Paris: PUF. Kingdon.

Kingdon John W., and Eric Stano 1984. Agendas, Alternatives and Public Policies. Boston: Little, Brown.

Kübler, Daniel, and Jacques de Maillard. 2009. Analyser les politiques publiques. Grenoble: Presses universitaires de Grenoble.

Mackintosh, Maureen, Parvati Raghuram, and Henry Leroi. 2006. A Perverse Subsidy: African Trained Nurses and Doctors in the NHS. Soundings 34(34): 103-113.

Mendy, Angèle F. 2010. Les migrations internationales des médecins africains: entre stratégies des acteurs, politiques nationales et débats internationaux. Les cas du Royaume Uni, de la France et de la Suisse. Thèse de doctorat, sciences sociales et politiques, Université de Lausanne, Suisse.

Mendy, Angèle F., 2016. Etre médecin africain en Europe. Paris: Editions Karthala.

Mendy, Angèle F., 2018. Recruitment Policies of Non-EU/EEA Nurses and Ethical Issues: Comparative Study of the British, Swiss and French Cases. Pp. 320-336 in High-Skilled Migration: Drivers, Dynamics and Policies. Oxford: Oxford University Press.

Mendy Angèle F. 2019. Professional Integration of African Migrant Doctors in France. Pp. 223-225 in Family Strategies, Diaspora and Investments, edited by Eyebiyi, P. Elieth, and Angèle F. Mendy. Ottawa :Lasdel \& Daraja Press.

Merrien, Francois-Xavier. 1990. Etat et politiques sociales : contribution à une théorie «néoinstitutionnaliste». Sociologie du travail 32(3): 67-294.

Merrien, Francois-Xavier, Raphael Parchet, and Antoine Kernen. 2005. L'Etat social. Une perspective internationale. Paris: Armand Colin.

Murray, Alasdair. 2011. Britain's Points Based Migration System. London: Centre Forum London.

NHS England. 2013. A refreshed Equality Delivery System for the NHS. London: NHS England.

Nohrstedt, Daniel, and Christopher M. Weible. 2010. The Logic of Policy Change After Crisis: Proximity and Subsystem Interaction. Risk, Hazards \& Crisis in Public Policy 1(2): 1-32.

North, Douglass C., 1990. A Transaction Cost Theory of Politics. Journal of Theoretical Politics 2(4): 355-367.

Nursing and Midwifery Council (NMC). 2011. Registering As a Nurse or Midwife in the United Kingdom. For Applicants Trained Within the EU or EEA'. Nursing and Midwifery Council.

Nursing and Midwifery Council (NMC). 2014. Changes to Overseas Registration. For Applicants Educated Outside the European Union and European Economic Area. Effective From Autumn 2014. Nursing and Midwifery Council.

OCDE. 2004. La migration des professionnels de santé : évaluation et enjeux à partir du cas sud-africain. Partie III. Pp. 121-160 in Tendances des migrations internationales. Paris: SOPEMI Edition 2003.

Pierson, Paul. 1996. The Path to European Integration: A Historical Institutionalist Analysis. Comparative Political Studies 29(2):123-163.

Pierson, Paul. 2000. Increasing Returns, Path Dependence, and the Study of Politics. American Political Science Review 94(2): 251-267.

Roe, Emery. 1994. Narrative Policy Analysis: Theory and Practice. Durham and London: Duke University Press.

Royal College of Nursing (RCN). 2013. Social Care in England. A Guide for Nursing Staff. London, RCN Policy and International Department.

Royal College of Nursing (RCN). 2014. Registration of overseas trained nurses in the UK. International comparisons and key issues for incoming nurses to ensure safe and effective practice. London, RCN Policy and International Department Policy briefing 01/14.

Sabatier, Paul. A., 1988. An Advocacy Coalition Framework of Policy Change and the Role of PolicyOriented Learning Therein. Policy Sciences 21(2-3):129-168. 
WHO. 2004. Fifty-Seventh World Health Assembly: Resolution WHA57.19. Geneva.

Woodward David, Nick Drager, Robert Beaglehole, and Debra Lipson. 2002. Mondialisation et santé : un cadre pour l'analyse et l'action. Bulletin de l'Organisation Mondiale de la Santé. Recueil d'articles (6) : 36-42

World Bank. 1995. World Bank Report 1995. Workers in an Integrating World. World Bank, New York: Oxford University Press.

World Trade Organization/World Health Organization (WTO/WHO). 2002. WTO Agreements \& Public Health. A Joint Study by the WTO and the WHO Secretariat. WTO/WHO. 